\title{
Electronic sources in libraries of Polish technical universities: yesterday and today
}

\author{
Danuta Rys, Anna Chadaj
}

\begin{abstract}
The aim of this article is to outline changes in the libraries of Polish technical universities, as a result of the proliferation of electronic information sources. Methods of gaining access to them are discussed. Results of a survey, which suggest that the increasing availability of e-resources does not go hand in hand with the development of skills for selecting, assessing and using these resources, are described. Usage statistics for three e-resources from three technical universities are also described. With the introduction of remote access, the number of user visits to the library decreased. Thus cultural activities, as well as adapting the library space to users' changing expectations, have become necessary to attract users. Libraries are becoming increasingly "open" to users' needs, and in addition to traditional tasks many of them have taken up the role of a university information centre.
\end{abstract}

\section{Introduction}

This article explores issues surrounding the usage of electronic resources in Polish universities. A literature review discusses the impact of technological developments on information provision, focusing particularly on electronic resources in Polish academic libraries. A study examining users' perceptions of eresources and the levels of usage of these resources is described. The study involved a survey of students at one Polish university, together with analysis of

\section{Authors}

Danuta Rys works in the Main Library of the AGH University in Cracow. She similarly focuses on e-sources, information literacy, user training, and bibliometrics.

Email: danuta.rys@bg.agh.edu.pl

Anna Chadaj works in the Main Library of the AGH University in Cracow. Her interests include information sources, information literacy, user training, and bibliometrics. 
usage figures for three separate electronic resources at three Polish universities. This article makes recommendations about user training and the promotion of eresources.

\section{Literature review}

The development of information technologies and the internet has led to many changes in libraries. OPAC catalogues have been created, and remote access to esources has become standard. In addition to subscribed electronic journals, books, and databases available on external servers, users can access academic resources through digital libraries. These changes have been reflected and described in library literature.

Jacquesson (1995) discussed the history and various aspects of the development of automation in libraries in Western Europe, the United States and Canada, considering issues such as functions of automated systems, OPAC catalogues and library networks. Dech (2012) provided a brief history of the use of technologies in libraries, focusing on library automation efforts of the IFLA's Mechanization Committee. He also discussed OPAC catalogues, the use of the internet in libraries and innovations such as smartphones, and electronic books readers.

Moghaddam (2009) focused on the development of databases from paper-based to web-based, including their functionality and search features. Other concerns included organising national consortia for licensing databases (Tollefsen and Gulliksen, 1999), managing electronic journals and user training (Kidd, 1997), licensed electronic resources management (Webb, 1998), cataloging and management policies (West and Miller, 2011), and user behaviour (Nicholas, 2010).

Changes which have taken place in Polish university libraries over the last several dozen years also have been the subject of many books, journal articles and conference materials. Nahotko (2004), chronicled the history of automation and computerisation in Poland, and Ścibor (1999) focused on issues regarding library software used in Polish libraries, such as CDS/ISIS (Computerised

Documentation Service / Integrated Set of Information Systems), as well as on the exchange of ideas between the libraries undergoing the process of computerisation. Ścibor's (1999) goal was to compare the state of the automation of Polish libraries to the international standards at the time. The automation of library processes by using integrated library systems was a topic tackled by Grabowska (1989), and Paluszkiewicz (1991). Dobrzyńska-Lankosz (2009) addressed the issue of the technology revolution and its effect on the methods of acquisition, preparation, storage, and circulation of collection materials in libraries.

Many authors have looked at the subject of electronic sources in Polish libraries. Dobrzyńska Lankosz (2002) wrote about the beginnings of computerisation, and the first electronic sources, while Górny (2002) presented basic models and trends in collection management, and changes which had taken place as the result of the introduction of electronic sources. Jańdziak (2010) discussed issues such as the range of e-sources available in libraries, issues surrounding the management of e- 
sources, the organisation of access, and new technologies facilitating the management of the collections of e-resources (such as open URL link resolvers, federated searching, and Open Journal Systems). The organisation of online access to subscribed e-sources, for example via HAN (Hidden Automatic Navigator) was outlined by Nabiałczyk (2007), while Stępniak (2010) dealt with the topic of financing and acquiring electronic resources. Sójkowska and Podgórski (2008) presented the results of a survey on the number of electronic sources at the university libraries, and the means of making them available.

Much attention has been devoted to digital libraries all over the world. The book E-Publishing and Digital Libraries: Legal and Organizational Issues (Iglezakis, Synodinou, and Kapidakis, 2011) discussed organizational and legal issues concerning digital libraries. Raitt (2000) presented an overview of digital initiatives in selected countries in Europe, including projects founded by the European Commission, while Greenstein and Thorin (2002) carried out a study of digital library programs run by academic libraries in the USA, members of the Digital Library Federation.

In Poland, Dobrzyńska-Lankosz (2010) discussed their features and their potential threat to traditional libraries. Kopka (2010) described the activity of the Digital Libraries Federation. A recent collection of articles devoted to digital libraries discussed issues such as quality assessment criteria (Janiak and Krakowska, 2012), the creation of digital libraries (Mazurek, Parkoła and Werla, 2012), and profiled Polish digital libraries.

\section{Libraries of Polish technical universities}

This study focuses on the libraries of three Polish technical universities.

The library of the AGH University of Science and Technology in Cracow was originally founded in 1919. Today, there are more than 34,000 students at the 16 faculties of the University. Apart from the Main Library, there are 15 faculty and 9 department libraries, and 3 libraries of other university units. The Main Library collections comprise 570,000 volumes of books and journals and 719,000 items consisting of patent descriptions, standards, maps, catalogues etc. The range of the library collection is consistent with the subject matter of studies and research carried out at the university, including mining, metallurgy, computer science and engineering (AGH, [2014]).

The library of Warsaw University of Technology was originally founded in 1915. In the academic year 2012/2013 the university had over 33,000 students. At present, the library and information system at the Warsaw University of Technology is comprised of more than 40 libraries: the Main Library, faculty and institute libraries, and libraries of other university units. They hold over 1,500,000 volumes of printed books and journals, and more than 18,000 electronic sources, such as e-journals, e-books, databases (Politechniki Warszawskiej, 2012).

Finally, this study also covers the library of Wroclaw University of Technology, which was established in 1946. The university had more than 33,500 students in $2012 / 2013$. The library collection comprises more than 900,000 volumes of books, journals and other documents (such as doctoral dissertations, standards, 
trade catalogues and CD-ROMs). The scope of the collection includes technical literature related to the areas covered by the university, such as mathematics, physics and chemistry, architecture, computer science, social and political science. Selected publications in other areas such as pedagogy, and psychology are also in the collection (Politechniki Wrocławskiej, [2014]).

\section{Electronic sources in the libraries of Polish technical universities}

A turning point in the dissemination of electronic resources was the introduction of sources offering access to full-text documents such as e-journals and e-books. The first full-text sources acquired by Polish technical libraries were Blackwell and Springer electronic journals and SAFARI and KNOVEL e-book collections.

In 1999 a SpringerLINK Polish library consortium was established. The coordinator of the project was the Main Library of the Warsaw University of Technology. 39 libraries belonging to the consortium gained online access to articles from 464 electronic journals. In 2001 two other consortia concerning fulltext journals were set up: ScienceDirect (Elsevier journals), and IDEAL (journals published by Academic Press).

At present, the majority of information sources at practically every technical university are in electronic form. Printed collections supplement electronic resources. Electronic resources available at Polish technical universities include ejournals, e-books, bibliographic, abstract and full-text databases, and documents created by academic staff.

Since 1st January 2010 the Ministry of Science and Higher Education, on the basis of a national licence, has provided all academic institutions and the Polish Academy of Science centres with access to basic electronic resources, including:

- ScienceDirect

- Wiley-Blackwell

- Web of Knowledge

- Springer

- EBSCOhost Web

- Scopus

Another way of gaining access to electronic resources is through acquisition by library consortia. Currently in Poland there are 15 library consortia (Interdyscyplinarne Centrum Modelowania Matematycznego i Komputerowego, 2014). The libraries of the largest technical universities participate in 14 consortia. The Ministry of Science and Higher Education partly subsidises such initiatives (up to 50 percent) with libraries covering the remaining costs from their own budgets.

Libraries of Polish technical universities also acquire e-sources individually through wholesalers or directly from publishers. The purchase of e-books often constitutes ownership of the books by the library. Online databases and 
collections of electronic sources are acquired via licence (such as a full-text database OnePetro).

This range of e-sources is supplemented by open access online collections, such as arXiv, and TechXtra. One example of a Polish language repository is Open AGH (Open AGH, [2014]), initiated in 2010 by the AGH University of Science and Technology. It is the first academic repository of Open Educational Resources in Poland available under the terms of a Creative Commons licence. Materials include online courses, course books, tests, and presentations from 102 academic fields. A similar service is the ENY Repository (Repozytorium ENY, 2013) of the Faculty of Electrical Engineering at the Wroclaw University of Technology.

\section{Methods}

Two research questions were identified:

- What are the users' views on e-resources provided by the Main Library of the AGH University of Science and Technology?

- How frequently are the electronic sources of information used?

In order to address these questions, a questionnaire survey was carried out among AGH University students. This survey was followed by a statistical analysis of the usage of selected e-resources at three leading technical universities (the Warsaw University of Technology, the Wroclaw University of Technology, and the AGH University of Science and Technology).

\section{$5.1 \quad$ The survey}

From 1st to 31st March 2009, staff at the Main Library of the AGH University conducted a survey to establish the level of knowledge of available e-resources, their usefulness and problems students had using them.

The questionnaire consisted of two parts. The first part included questions concerning the respondent's area of research, e-sources used, and training organised at the library. It consisted of 12 closed questions (single answers, and multiple answers), and 1 open-ended question, where respondents could write their comments and suggestions. In the second part, students gave personal information for statistical purposes, such as their gender, the type of course, and the faculty name.

The questionnaire was available on the AGH University Main Library website, and on the online catalogue website in the above mentioned period. 198 students completed the survey.

In addition to the survey the authors decided to carry out further research examining usage statistics for the electronic resources.

\subsection{Analysis of usage statistics}

In order to discover the extent to which electronic resources are used by AGH University faculty members and students in comparison with other leading technical universities in Poland, the authors carried out a comparative analysis of 
the usage of selected electronic sources in 2012. The data were provided by ICM Interdisciplinary Centre for Mathematical and Computational Modelling at the University of Warsaw (Wirtualna Biblioteka Nauki, 2012).The centre provides statistics for all electronic sources acquired via national licence or consortia.

The selected universities are comparable in terms of their number of students. The analysis investigated three sources of different types:

a) a subject full-text database (IEEE Xplore);

b) a collection of full-text electronic journals (Science Direct);

c) an interdisciplinary bibliographic and abstract database (Web of Science).

The investigation compared their usage at three universities in the period from 2007 to 2011. The available data enabled the authors to compare the number of full texts downloaded by users in the case of IEEE Xplore and Science Direct, and the number of searches in the case of Web of Science.

\section{Findings}

\subsection{Survey results}

As the number of respondents was relatively low, the research cannot be considered representative; however, it provided some initial insights into perceptions of electronic resources.

The research showed a lack of student awareness of e-resources. Most students $(56 \%)$ admitted that they either did not know the electronic sources offered by the library at all, or did not know them adequately. Students mostly drew information on electronic sources from the Main Library website (54\%), from acquaintances (41\%), or from lecturers (25\%).

Students' choice of electronic sources most frequently depended on the ease of access $(59 \%)$, relevance to the topic (45\%) and their lecturer's recommendation $(44 \%)$. Some students pointed out that the library did not offer electronic information sources for their subjects (17\%). These answers were given by the students in the field of mechanical engineering and robotics, and environmental protection, for which no subject databases were provided by the library. However, students from other faculties which were supported by appropriate subject databases were among the $17 \%$ of respondents who believed the library did not offer resources specific to their field of study

Most e-resources contain publications only in English, which was a problem to $7 \%$ of respondents. Students most commonly reported the following problems:

- finding relevant publications (31\%);

- obtaining too many results (22\%);

- lack of access to full text of articles (17\%).

Our interpretation of these data is that difficulties in finding relevant results could be caused by the improper selection of e-resources. We also believe that obtaining 
too many results could be a consequence of the lack of skills in phrasing or refining a search.

A general trend observed in the data received was that students who had direct contact with the library services (for example those using e-resources in the Reference Department, or students who had completed training in information sources in the library) had more knowledge about these resources, and their searches appeared to be more effective.

A detailed report on the survey results was published in Chadaj and Turecka (2009). In the survey responses, AGH University students themselves seemed to suggest that their awareness of electronic resources was inadequate. The authors therefore decided to compare the usage statistics for selected e-resources at AGH University, Warsaw University of Technology and Wroclaw University of Technology. The findings of this research are presented below.

\section{$6.2 \quad$ Usage statistics}

\subsubsection{IEEE Xplore usage}

IEEE Xplore is a full-text database providing access to documents in electrical engineering, computer science and electronics, published by the IEEE (Institute of Electrical and Electronics Engineers) and its publishing partners.

Figure 1 presents statistical data showing the number of downloaded full texts.

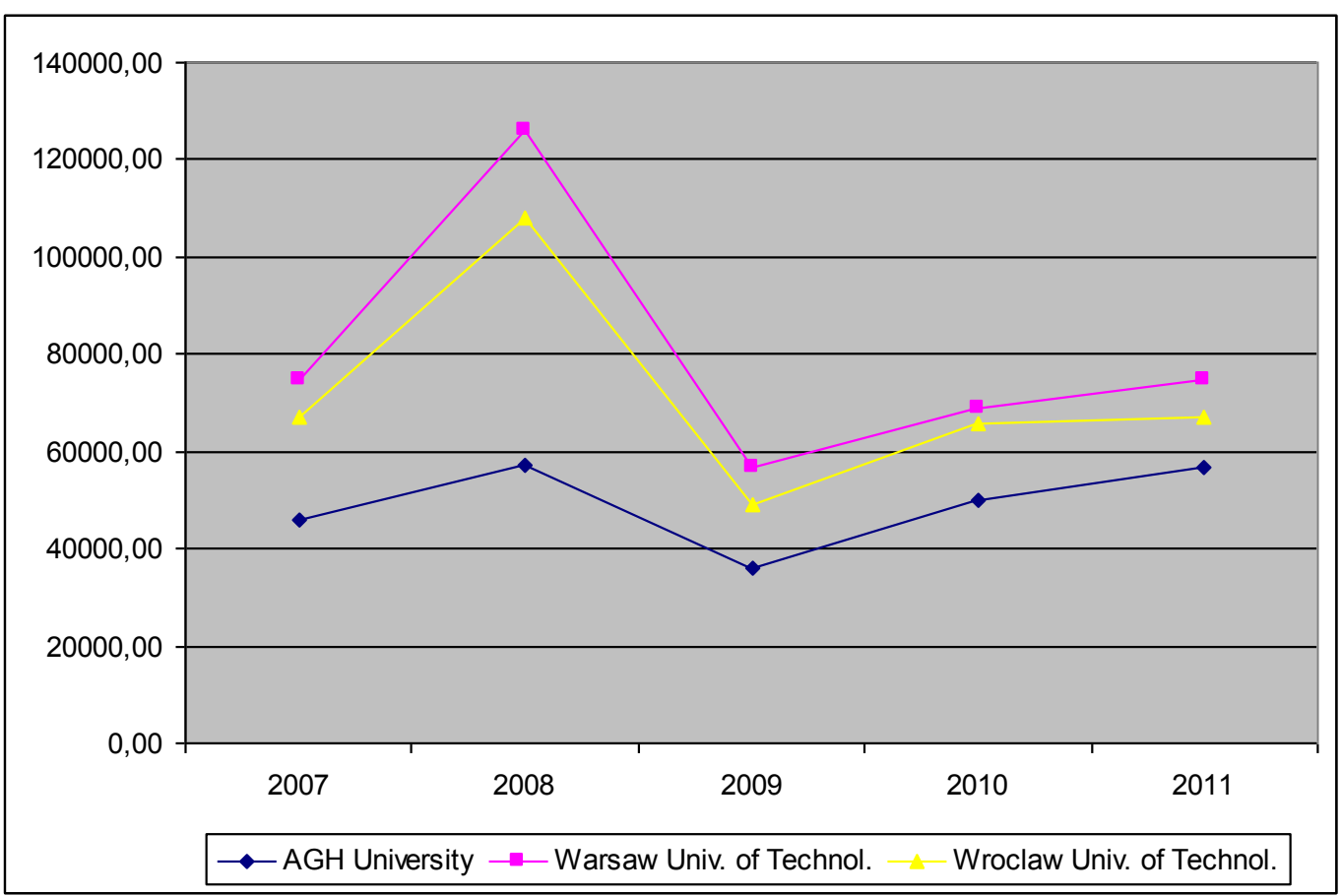

Figure 1: The number of full texts downloaded from IEEE Xplore in years 2007-2011.

The analysis shows that after an initial period of increased interest, the IEEE Xplore usage fell in 2009. According to IEEE Xplore's publisher, it was in that year that Google decided to discard their previous IEEE Xplore metadata index 
and completely rebuild an index of over 2.5 million IEEE Xplore metadata records. This action may have impacted the ability of students to find IEEE Xplore articles in Google and may have affected IEEE Xplore usage. (IEEE Xplore and Google, 2013). Since then the statistics show a small rise in IEEE Xplore usage at all three universities.

\subsubsection{Science Direct usage}

Science Direct is a leading full-text database. The National Licence in Poland provides Polish scientific institutions with access to more than 2,100 peerreviewed journals published by Elsevier.

Figure 2 presents statistical data concerning the number of full texts of articles downloaded from Science Direct.

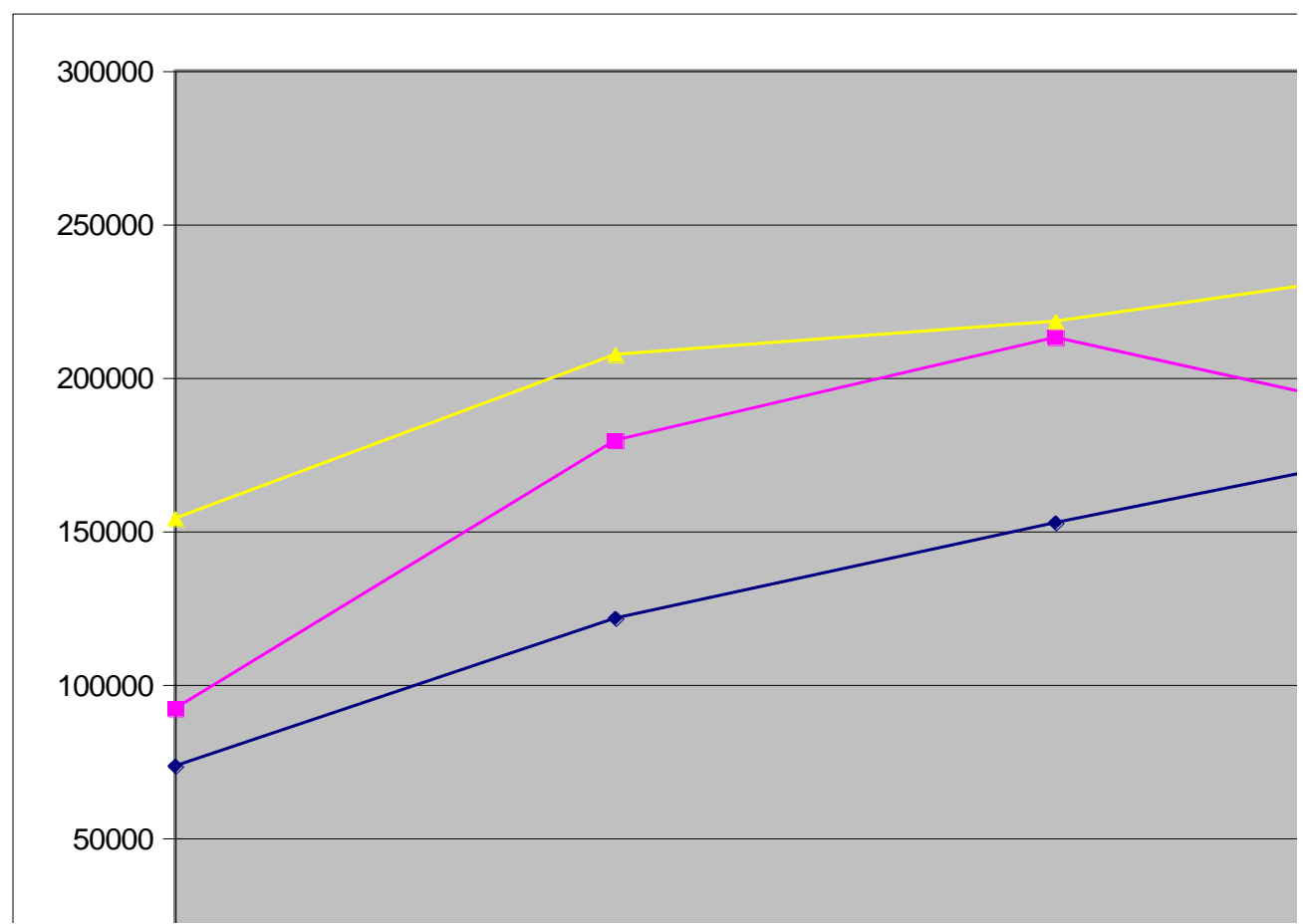

Figure 2: The number of full texts downloaded from Science Direct in years 2007-2011.

The analysis shows the increasing popularity of this source at the Wroclaw University of Technology and at the AGH University of Science and Technology. The usage of Science Direct at the Warsaw University of Technology slightly dropped in 2010. It is not clear why this is the case.

\subsubsection{Web of Science usage}

Web of Science provides access to the world's leading citation databases. It covers over 12,000 of the highest impact journals worldwide, including open access journals and over 160,000 conference proceedings from more than 250 disciplines (Web of Science, 2014). Figure 3 shows statistics for the number of searches carried out in this database at each of the three universities. 


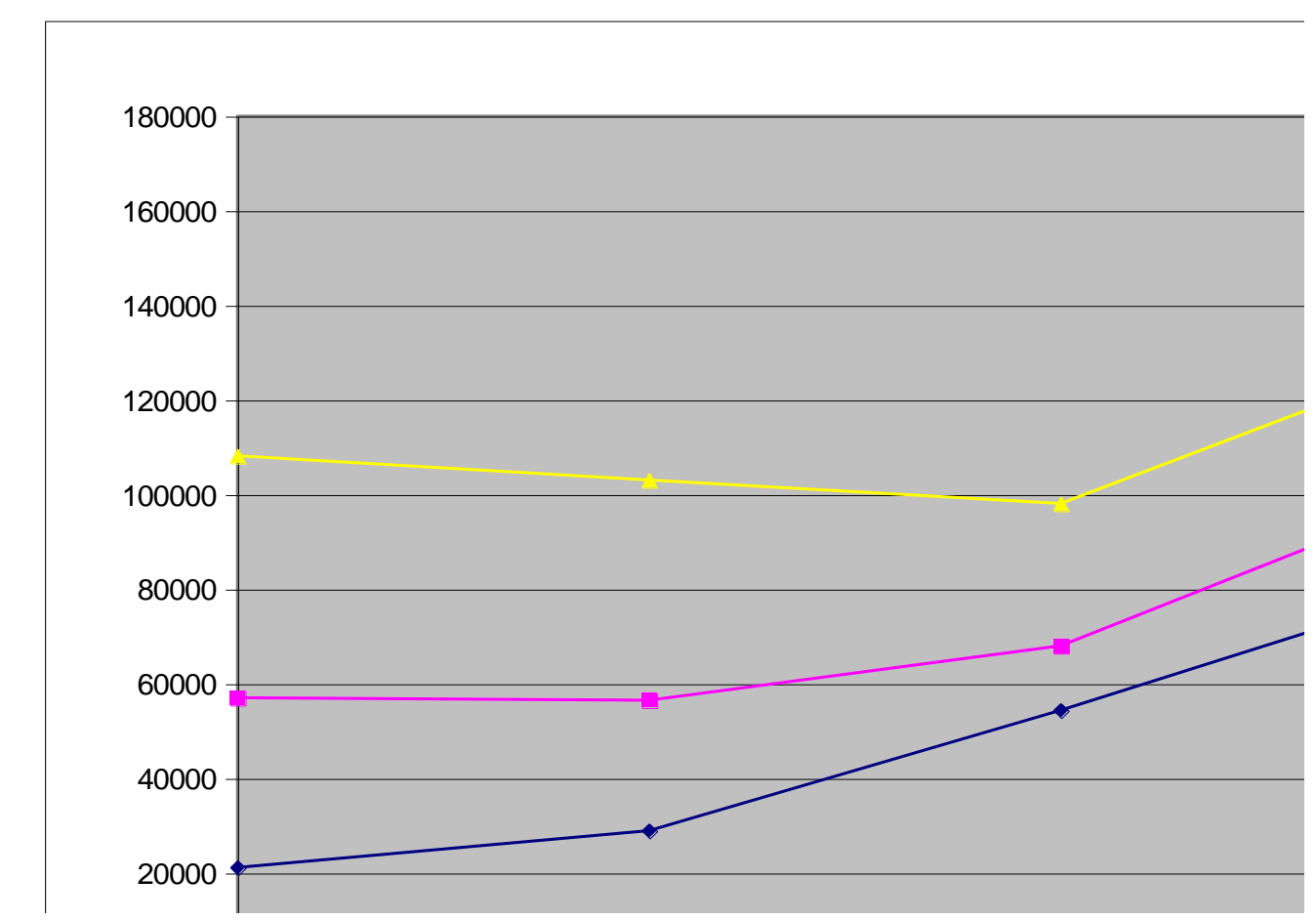

Figure 3: Searches carried out in Web of Science, 2007-2011.

Web of Science usage in Poland is relatively high in comparison to usage figures for other bibliographic and abstract databases. This may be due to the fact that it provides information about citation counts and h-index values for scholarly articles; information which is required for assessing staff, faculties and institutions. The figures show an increase in the usage of Web of Science at the Wroclaw University of Technology and at the AGH University of Science and Technology. However, in 2011 usage of the resource at the Warsaw University of Technology decreased. This could partly be explained by the fact that in that year another interdisciplinary citation database, SCOPUS, was provided through a national licence.

Despite a comparable number of users, the usage of analysed e-sources at the AGH University of Science and Technology is lower than at the two other leading technical universities in Poland.

\section{Discussion}

As the results of the research showed that student awareness and usage of electronic resources were at a relatively low level, steps were taken to address the issues arising from the research.

\subsection{User training to promote e-resources}

The survey results showed that students who had participated in the library training seemed to have a better knowledge of electronic resources and could use them more efficiently. Therefore attempts were made to extend this training to a wider group of users. 
The training syllabus at the Main Library of the AGH University of Science and Technology has been extended and now includes:

- introductions to resources based on students' syllabi in their faculties;

- training in how to use selected resources;

- literature searching for undergraduate and postgraduate dissertations;

- compiling bibliographies;

- introduction to citation rules and to complying with copyright regulations.

Classes are run by library staff for groups of approximately 15 people and are usually between 90 to 135 minutes.

Despite informing all faculties about the survey results and extending the training offer the response fell short of expectations. At present, due to the ongoing renovation and extension of the library building, training has been temporarily suspended. When the work is completed, and the multimedia training room is ready for use, further promotion and extension of the training offer are planned. Proposed topics and dates of training sessions will be placed on the library website and on faculty websites. The library also plans to introduce additional, tailor-made training sessions for interested users on demand.

\subsection{Promotion of e-resources}

Steps were taken to address the relatively low use of e-resources at AGH University in comparison with other leading technical universities, as revealed by the usage statistics. Library website information was modified to enable users to browse e-resources according to their subject. In addition, new materials were prepared in electronic form and in print, including information leaflets, folders, posters, presentations and guides.

\section{Conclusion}

At present, electronic resources, such as bibliographic and abstract databases, collections of full-text journal articles, and other electronic materials are standard in the libraries of Polish technical universities. Users can access these resources in the library, or remotely.

Basic electronic resources are available for all academic institutions through a national licence. Access to specialised, licensed bibliographic, abstract and fulltext databases can be gained through library consortia, or on the basis of individual licence agreements between libraries and publishers.

Individual libraries present information about their electronic resources on their websites. Electronic resources are usually arranged in alphabetical order or according to subject. Subjects mostly match the courses offered by particular universities, and include both commercial and open access databases, collections of full-text e-journals and e-books, and free catalogues of selected internet resources. 
The usage of electronic sources is gradually increasing. However, users encounter problems selecting appropriate sources and using them effectively. Therefore, training also needs to be provided to a larger number of users and training programs should be customised to meet users' specific needs. This may involve training in small groups, one-to-one classes or tailor-made training sessions.

User research provides valuable information about user knowledge of e-resources, the frequency of use, and the difficulties users face using these resources. Periodic repetition of the research will facilitate the adjustment of training programmes to users' needs and should help to raise awareness of e-resources.

One potential drawback of the increasing popularity of e-sources and the opportunity for remote access to them is that levels of contact between users and the library may diminish. In order not to lose their significance within their academic communities, libraries ought to be aware of ongoing developments and should modernise their services appropriately.

In order to support education and research adequately librarians working at Polish universities, especially technical ones, ought to improve their own qualifications constantly though participation in training events, seminars, webinars, and in local, national and international conferences.

\section{References}

AGH ([2014]) Biblioteka Glówna AGH [The Main Library of the AGH University of Science and Technology] [online]. URL: http://www.bg.agh.edu.pl [accessed 9.11.14].

Chadaj, A. and Turecka, D. (2009) Wiedza na temat elektronicznych źródeł informacji i efektywność ich wykorzystania na podstawie badań ankietowych [The knowledge of electronic information sources and the effectiveness of usage based on survey research], Praktyka i Teoria Informacji Naukowej i Technicznej, 17(1-2), 19-25.

Dech, L. (2012) Technology in libraries: past and present, PNLA Quarterly, 76 (2), 56-60.

Dobrzyńska-Lankosz, E. (2010) Biblioteka cyfrowa jako jeden z przejawów aktywności współczesnej biblioteki akademickiej [A digital library as an indication of a modern university library activity]. In: Library Conference, Technical University of Lodz, Biblioteka w kryzysie czy kryzys w bibliotece? [The library in crisis or crisis in the library]. Lodz: Library of Poznan University of Technology. 63-68.

Dobrzyńska-Lankosz, E. (2009) Tradycja a nowoczesność - temat stary jak świat [Tradition and modernity - a subject as old as the world] In: Lodz University Library Conference, Stare i nowe w bibliotece - wspótpraca czy konkurencja [The old and the new solutions in the library - cooperation or competition]. Lodz: University of Lodz. 15-23. 
Dobrzyńska-Lankosz, E.(2002) Wczoraj fantazja, dzisiaj - rzeczywistość, czyli o komputeryzacji polskich bibliotek akademickich słów kilka [Yesterday - fantasy, today - reality, or a few words on the computerisation of Polish university libraries] In: Jazdon, A. (ed.) Stan i potrzeby polskich bibliotek uczelnianych [The condition and needs of Polish university libraries] Poznan: Adam Mickiewicz University. 125-147.

Górny, M. (2002) Od gromadzenia zbiorów do zarządzania zbiorami. [From acquisitions in a collection to managing library resources]. In: Jazdon A. (ed.) Stan i potrzeby polskich bibliotek uczelnianych [The condition and needs of Polish university libraries] Poznan: Adam Mickiewicz University. 105-124.

Grabowska, M. (1989) Katalogi online [Online catalogues], Przegląd Biblioteczny, 2, 111-123.

Greenstein, D. and Thorin S. E. (2002). The digital library: a biography [online]. Washington: Digital Library Federation, Council on Library and Information Resources. URL: http://www.clir.org/pubs/reports/pub109/pub109.pdf [accessed 25.4.14].

IEEE Xplore and Google. Engineering and Mathematics @ City. Blog at WordPress.com [online]. URL:

http://engineeringandmaths.wordpress.com/2010/06/28/ieee-xplore-and-google/ [accessed 25.5.13].

Iglezakis, I., Synodinou, T. and Kapidakis, S. (2011). E-Publishing and Digital Libraries: Legal and Organizational Issues. Hershey: IGI Global.

Interdyscyplinarne Centrum Modelowania Matematycznego i Komputerowego (2014) Wirtualna Biblioteka Nauki [Virtual Library of Science] [online]. URL: http://vls.icm.edu.pl [accessed 9.11.14].

Jacquesson, A. (1995) L'informatisation des bibliotheques. Historique, strategie et perspectives. Paris : Electre - Editions du Cercle de la Librairie.

Janiak, M. and Krakowska, M. (2012) Ocena jakości bibliotek cyfrowych. [Quality assessment of digital libraries] In: Janiak. M., Krakowska, M., and Próchnicka, M. (ed.) Biblioteki cyfrowe [Digital libraries]. Warszawa: SBP. 135178.

Jańdziak, A. (2010) Elektroniczne zasoby bibliotek akademickich [University libraries electronic resources] In: Czerwińska E. and Jańdziak A. (ed.) Biblioteka wśrodowisku współczesnej uczelni wyższej [The library in the modern university environment] Opole: Oficyna Wydawnicza Politechniki Opolskiej. 111-118.

Kidd, T. (1997) Electronic journals management. Some problems and solutions. Managing Information, 4, 10, 25-26.

Kopka, B. (2010) E-biblioteka. Dokąd zmierzamy? [E-library. Where are we heading?] In: Czerwińska E. and Jańdziak A. (ed.) Biblioteka w środowisku współczesnej uczelni wyższej. [The library in the modern university environment] Opole: Oficyna Wydawnicza Politechniki Opolskiej. 99-108.

Mazurek, C., Parkoła, T. and Werla, M. (2012) Tworzenie i rozwój bibliotek cyfrowych [The creation and development of digital libraries] In: Janiak. M., 
Krakowska, M. and Próchnicka, M. (ed.) Biblioteki cyfrowe [Digital libraries] Warszawa: SBP. 341-361.

Moghaddam, A. I. (2009) Databases: From paper-based to web-based, Library Philosophy and Practice, (March), 1-6.

Nabiałczyk, K. (2007) Organizacja zdalnego dostępu do licencjonowanych elektronicznych zasobów informacji w bibliotekach uczelni wyższych [The organisation of online access to subscribed electronic sources of information in university libraries], Przeglad Biblioteczny, 2, 221-232.

Nahotko, M. (2004) Komputeryzacja bibliotek naukowych w Polsce [Computerisation of academic libraries in Poland], Konspekt [online] 19. URL: http://www.wsp.krakow.pl/konspekt/19/nahotko2.html [accessed 29.4.13].

Nicholas, D., Williams, P. and Rowlands, I. (2010) Researchers' e-journal use and information seeking behavior, Journal of Information Science, 36(4), 494-516.

Open AGH ([2014]) Open AGH [online]. URL:

http://open.agh.edu.p1/index.php?id=1\&theme=1280 [accessed 9.11.14].

Paluszkiewicz, A. (1991) Rola formatu i kartotek wzorcowych w komputeryzowanych katalogach bibliotecznych [ The role of bibliographic format and authority files in computerised library systems], Przeglad Biblioteczny, (3/4), 275-279.

Politechniki Warszawskiej (2012) Biblioteka Główna Politechniki Warszawskiej [The Main Library of the Warsaw University of Technology] [online]. URL: http://www.bg.pw.edu.pl [accessed 9.11.14].

Politechniki Wrocławskiej ([2014]) Centrum Wiedzy i Informacji NaukowoTechnicznej-Biblioteki [Centre of Knowledge and Science and Technology Information - Library] [online]. URL:

http://www.biblioteka.pwr.wroc.pl/index.dhtml [accessed 9.11.14].

Raitt, D. (2000) Digital library initiatives across Europe, Computer Libraries, 20(10), 1-9.

Repozytorium Eny Politechnika Wroclawska ([2014]) Repozytorium Eny. Politechnika Wroclawska [ENY Repository of the Wroclaw University of Technology] [online]. URL: http://zet10.ipee.pwr.wroc.pl/ [accessed 9.11.14].

Sójkowska, I. and Podgórski, F. (2008) Elektroniczne źródła informacji naukowej w bibliotekach szkół wyższych: Badania ankietowe [Electronic sources of information: A questionnaire survey], Zagadnienia Informacji Naukowej, 1, 4558.

Stępniak, J. (2010) Polityka gromadzenia zbiorów elektronicznych - od samofinansowania do licencji krajowych [The policy of electronic resources development - from self-financing to the national consortium program]. In: Library Conference, Technical University of Lodz, Biblioteka w kryzysie czy kryzys $w$ bibliotece? [The library in crisis or crisis in the library]. Lodz: Library of Poznan University of Technology. 71-83. 
Ścibor, E. (1999) Rozdział wstępny do wydania polskiego [A preliminary chapter to the Polish edition]. In: Jacqueson, A. Automatyzacja bibliotek [Automation of libraries], Warszawa: Wydawnictwa Uniwersytetu Warszawskiego. 9-29.

Tollefsen S. and Gulliksen, M. (1999) Organizing national consortia for licensing bibliographic, citation and fulltext databases, Liber Quarterly, 9(4), 413-419

Web of Science (2014). Web of Science [online]. URL:

http://wokinfo.com/products_tools/multidisciplinary/webofscience/ [accessed 9.11.14].

Webb, J. (1998) Managing licensed networked electronic resources in a university library, Information Technology and Libraries, 17(4), 198-206

West, W. L. and Miller H. S. (2011) Electronic journals: cataloguing and management policies in academic libraries, Serials Review, 37(4), 267-274

\section{Open access and copyright}

Library and Information Research is an open access journal. A freely available copy of this paper may be downloaded from the journal's website:

http://www.lirgjournal.org.uk

Copyright and associated moral rights in works published in Library and Information Research are retained by the author(s) but this paper may be used freely, with proper attribution, in educational and other non-commercial settings. 